\title{
Plasma DNA in the diagnosis of pulmonary embolism
}

\author{
WAYNE R BREITWIESER, CRAIG W HARTMAN, WILSON S MORRIS, MILDRED K \\ FLEETWOOD, JOHN A BAXTER, ROBERT E ALBERTINI
}

From the Department of Thoracic Medicine, Geisinger Medical Center, Danville, Pennsylvania, USA

ABSTRACT To assess the diagnostic value of measuring free plasma deoxyribonucleic acid (DNA) in patients suspected of having pulmonary embolism, we prospectively assayed the plasma of 40 consecutive patients who underwent pulmonary angiography for the presence of free plasma DNA. Fifteen of them had angiographic evidence of pulmonary embolism. Of these 15 only two (13\%) had a positive result in the test for free double-stranded plasma DNA. We concluded that measuring free double-stranded plasma DNA is of no value in the diagnosis of pulmonary embolism.

Pulmonary embolism is the most common preventable cause of hospital death ${ }^{1}$ and the third most frequent cause of death in the United States. ${ }^{2}$ In making the diagnosis of pulmonary embolism, the clinician requires diagnostic studies which are both sensitive and specific. Recently, Sipes and coworkers ${ }^{3}$ reported that detection of free plasma DNA was $83 \%$ sensitive and "extremely specific" for the diagnosis of pulmonary embolism. In their study the diagnostic criterion for a pulmonary embolism was a "high-probability" lung scan. Radionuclide perfusion scanning is sensitive but relatively non-specific in the diagnosis of pulmonary embolism. ${ }^{4}$ Pulmonary angiography with selective lobar and segmental injection is both highly sensitive and specific. ${ }^{4}$ The purpose of our study was to assess the value of plasma DNA in the diagnosis of pulmonary embolism, the pulmonary angiogram being used as the diagnostic standard.

\section{Methods}

Forty consecutive patients who underwent pulmonary angiography at Geisinger Medical Center because of suspected pulmonary embolism had blood collected before angiography in EDTA (ethylene diamine tetra-acetic acid) Vacutainer tubes. We obtained the informed consent of each patient in accordance with the standards of our committee on human experimentation before the drawing of their blood. No attempt was made to

Address for reprint requests: Dr RE Albertini, Department of Thoracic Medicine, Geisinger Medical Center, Danville, Pennsylvania 17822 , USA. exclude patients with diagnoses known to be associated with raised concentrations of free plasma DNA.

Pulmonary angiograms were performed by an experienced angiographer using the Seldinger technique via a femoral vein. All except one of the studies were performed within 48 hours of the onset of symptoms. The single exception was performed within 72 hours. Standard diagnostic criteria of intravascular filling defects and vessel "cut-offs" were applied. All angiograms were read without knowledge of the results of the plasma DNA assay.

Forty plasma specimens from patients with systemic lupus erythematosus that were positive for antibody to double-stranded DNA by the Crithidia luciliae assay were screened for potential use in the counterimmunoelectrophoresis (CIE) method for the detection of free plasma DNA. A specimen producing a visible precipitin line within the $1.5 \mu \mathrm{g}$ DNA standard was used for testing patients' specimens. This specimen had an anti-DNA titre of 1/320.

The DNA standard (Sigma Chemical Corporation, 3500 Dekalb Street, St Louis, Missouri 63118) was dissolved to make a solution of $100 \mathrm{mg} / \mathrm{dl}$. The positive control in each plate was $1.5 \mu \mathrm{g} / \mathrm{ml} .^{6}$

The plasma was separated from the patients' blood samples by centrifugation and heated for one hour at $56^{\circ} \mathrm{C}$ to destroy complement activity. The plasma samples were then frozen at $-70^{\circ} \mathrm{C}$ until tested at a later date. Counter-current electrophoresis was performed on commercially prepared plates (Cordis Laboratories, Miami, Florida 33137) by placing the antibody in the anodal well and the patient's sample in the cathodal well. Barbital acetate buffer (pH 8.2 \pm 0.2 ) was freshly prepared on the day of use. An adjustable elec- 
trophoretic chamber was used with $\mathbf{4 0}$ milliamps ( 5 milliamps $/ \mathrm{cm}$ ) for 30 to 60 minutes at ambient temperature. The plates were then placed on a reading device providing oblique lighting with magnification. The results were recorded at 2 hours and 24 hours as either positive or negative. Positive and negative controls were included on each plate, which were also frozen at $-70^{\circ} \mathrm{C}$ in aliquot amounts.

\section{Results}

The pulmonary angiograms of 15 out of 40 patients were positive for pulmonary embolism. Of these 15 patients, two $(13 \%)$ had a positive result in the test for free plasma DNA. None of the 25 patients with negative angiograms had a positive result in the test for free plasma DNA. The patients with negative angiograms had various diagnoses, including congestive heart failure, pneumonia, sepsis, recent abdominal surgery, cardiomyopathy, metastatic cancer, pleural effusion of unknown aetiology, and chest wall pain.

\section{Discussion}

Our study was designed to assess the diagnostic value of measuring free plasma DNA in patients with acute pulmonary embolism confirmed by pulmonary angiography. Our data show a sensitivity of $13 \%$ in a group of 15 patients with angiographically proved pulmonary emboli. An $83 \%$ sensitivity was found in a previous study, in which a pulmonary embolism was established on the basis of a highprobability lung scan only. ${ }^{3}$ The difference between our findings and those reported by others ${ }^{356}$ is probably due to the specificity of the criteria used to diagnose a pulmonary embolus. Lung scans are relatively non-specific by comparison with pulmonary angiography. Even when ventilation scanning is combined with perfusion scanning absolute specificity is rarely possible.?

It is also possible that these discrepancies in results are due to a difference in the antibody used to detect free plasma DNA. Because the Crithidia luciliae assay was used in screening for a test serum our antibody would detect only double-stranded DNA. It was, however, double-stranded DNA that was reported to be present in the plasma of patients with pulmonary embolism. ${ }^{56}$

The fact that our study showed no false positives is surprising in view of the multiple conditions in which free plasma DNA has been found. The sensitivities of our antiserum and the antiserum used by Sipes et al were similar. The lack of false positives in our study may simply reflect the specificity of our antiserum for double-stranded DNA, although this was not documented. Sipes et al, ${ }^{3}$ Barada et al, ${ }^{5}$ and Davis and Davis ${ }^{6}$ used antiserum that contained precipitating antibodies to both double-stranded and single-stranded DNA. The finding of free serum single-stranded DNA in a variety of disorders by Koffler $e t a l^{8}$ may account for the high rate of false positives noted in some of the previous studies. The finding of no single-stranded DNA by Davis and Davis in their series of 437 sera $^{6}$ suggests that there is an antibody in the sera, yet to be identified, that accounts for some of the false-positive results.

Our findings indicate that very few pulmonary emboli can be detected by performing an assay for free double-stranded plasma DNA. In addition, since many conditions other than pulmonary embolism may be associated with free plasma DNA, a positive result in the plasma DNA assay is difficult to interpret unless we exclude patients with these conditions (the postoperative state, collagen vascular diseases, renal failure, hypertension, lymphoproliferative disorders, and high-dose corticosteroid treatment among others). A few patients (three out of 10) in Barada's study gave a negative result in the plasma DNA assay at the time of diagnosis by lung scan but they became positive 24 hours later. ${ }^{5}$ This delayed positivity would reduce the utility of this test during the critical decision-making period in the evaluation of a potential case of pulmonary embolus.

It was hoped that this simple, non-invasive test might be accurate and sensitive enough to eliminate the need for pulmonary angiography in an appreciable number of patients. Our results indicate that a plasma assay for double-stranded DNA is not sensitive enough to be of any value in the diagnosis of pulmonary embolism.

This work was supported by a grant from the Institute for Medical Education and Research at Geisinger Medical Center.

\section{References}

${ }^{1}$ Morell MT, Dunnill MS. The postmortem incidence of pulmonary embolism in a hospital population. $\mathrm{Br} J$ S Surg 1968;55:347-52.

${ }^{2}$ Dalen JE, Alpert JE. Natural history of pulmonary embolus. Prog Cardiovasc Dis 1975;17:259-70.

${ }^{3}$ Sipes JN, Suratt PM, Teates ED, Barada FA, Davis JS, Tegtmeyer CJ. A prospective study of plasma DNA in the diagnosis of pulmonary embolus. Am Rev Respir Dis 1978;118:475-8.

${ }^{4}$ Moses DC, Silver TM, Bookstein JJ. The complimentary role of chest radiography, lung scanning, and selective pulmonary angiography in the diagnosis of pulmonary embolus. Circulation 1974;49:179-88.

5 Barada SA, Suratt PM, Davis JS, et al. Free plasma 
DNA in patients with pulmonary embolus. South Med J 1980;73:345-50.

${ }^{6}$ Davis GL, Davis JS. Detection of circulating DNA by counterimmunoelectrophoresis. Arthritis Rheum 1973;16:52-8.

' Neuman RD, Sostman HD, Gottschalk A. Current status of ventilation and perfusion imaging. Semin Nucl Med 1980;10:198-217.

${ }^{8}$ Koffler D, Agnello V, Winchester R, Kunkel H. The occurrence of single stranded DNA in the serum of patients with systemic lupus erythematosus and other diseases. J Clin Invest 1973;52:198-204. 